\title{
Elevation of soluble major histocompatibility complex class I related chain A protein in malignant and infectious diseases in Chinese patients
}

\author{
Xiaoxin Jiang 1,2,3, Ju-Fang Huang ${ }^{3}$, Zhi Huo ${ }^{1}$, Qiuqui Zhang ${ }^{1}$, Yan Jiang ${ }^{1}$, Xiaoping Wu' ${ }^{1}$, Yanwen Li', \\ Guanmin Jiang ${ }^{1}$, Leping Zeng ${ }^{3}$, Xiao-Xin Yan ${ }^{3^{*}}$, Ping Yu ${ }^{2}$ and Renxian Cao ${ }^{{ }^{*}}$
}

\begin{abstract}
Background: Elevation of soluble major histocompatibility complex class I chain-related gene A (sMICA) products in serum has been linked to tissue/organ transplantation, autoimmune diseases and some malignant disorders. Cells infected by microbiological pathogens may release sMICA, whereas less is known whether and to what extent serum sMICA levels may change in infectious diseases.

Methods: The present study determined serum SMICA levels by enzyme-linked immunosorbent assay (ELISA) in a southern China population, including patients $(n=1041)$ suffering from several types of malignant and infectious diseases and healthy controls $(n=141)$.

Results: Relative to controls, serum sMICA elevation was significant in patients of hepatic cancer, and was approaching statistical significance in patients with lung, gastric and nasopharyngeal cancers. sMICA elevation was also associated with some bacterial (Enterobacteriaceae, Mycobacterium tuberculosis, non-fermenting Gramnegative bacteria and Gram-positive cocci), viral (hepatitis B and C) and the Microspironema pallidum infections.

Conclusion: Serum sMICA levels may be informative for the diagnosis of some malignant and infectious diseases. The results also indicate that microbiological infections should be considered as a potential confounding clinical condition causing serum sMICA elevation while using this test to evaluate the status of other disorders, such as cancers, host-graft response and autoimmune diseases.
\end{abstract}

Keywords: MHC, sMICA/B, NKG2D, Cancer diagnosis, Serum

\section{Background}

A host organism can mount immune responses to "foreign" antigens during tissue transplant, against infectious pathogens and under autoimmune conditions. The major histocompatibility complex (MHC) or human leukocyte antigen (HLA) genes located in chromosome 6 encode the classical class I gene products that are involved in such immune responses. Thus, MHC class I (HLA-A, -B and -C) and class II (HLA-DR, -DQ and -DP) genes produce

\footnotetext{
* Correspondence: yanxiaoxin@csu.edu.cn; caorenxian@hotmail.com ${ }^{3}$ Department of Anatomy and Neurobiology, Xiangya School of Medicine, Central South University, Changsha, Hunan 410013, China

'The First Affiliated Hospital, Nanhua University, Hengyang 421001, China Full list of author information is available at the end of the article
}

antigen-presenting molecules that stimulate $\mathrm{CD} 8+$ and CD4+ T cells activation. MHC class III or central MHC proteins perform various immune functions by participating complement and cytokine activities [1-4].

The human major histocompatibility complex class I chain-related genes (MIC) are lately discovered genes located on chromosome 6 in the region encoding the classic MHC products, This set of genes encodes protein products performing distinct immune functions than antigen presentation. The MIC region consists of 7 loci encoding two functional genes, namely the human major histocompatibility complex class I chain-related gene A $(M I C A)$ and $\mathrm{B}(M I C B)$, with the remainder (MICC-MICG) being pseudogenes [5,6]. Specifically, the MICA gene is about $11.7 \mathrm{~Kb}$

\section{() Biomed Central}


in length, and is transcribed into a 1382 bp mRNA that has 6 exons separated by 5 introns. Mature MICA polypeptide consists of 383 amino acid residues (43 Kda), containing a leading sequence translated from exon 1 , the $\alpha 1$ to $\alpha 3$ structural domains encoded by exon 2 to 4 , and a transmembrane domain and a cytoplasmic domain that are determined by exons 5 and 6 , respectively. The transmembrane domain encoded by exon 5 is rich of GCT microsatellite repeats, resulting in a great polymorphism. The MICB gene is organized in a similar manner to that of MICA, and shares $\sim 91 \%$ base-pair sequence with the latter. Evidence suggests that the MICB gene also exhibits a certain degree of polymorphism [6-12]. MICA and MICB, including their polymorphism conditions, may relate to the susceptibility to cancer and infectious diseases among individuals, although the underlying mechanisms remain less clear at the present [13-23].

In addition to their membrane-bound forms, MICA and MICB can be released from the surface of tumor and infected cells following proteolytic cleavages, yielding soluble MICA (sMICA) and MICB (sMICA) in serum. By binding to NKG2D receptor, soluble MICA/B molecules may block the activation of effector lymph cells by MICA/B, thereby facilitate the escape of tumor or infected cells from immunosurveillance [1,2,24-30]. In patients with some types of cancers, serum levels of sMICA/B are elevated, whereas the NKG2D expression on $\mathrm{NK}$ and/or $\mathrm{CD} 8^{+} \mathrm{T}$ cells are downregulated. As such, soluble MICA/B in the circulation may therefore play an important biological role in modulating immune response $[1,25,26]$.

sMICA/B have been used as potential biomarkers for assessing chronic graft-host immune response as well as the status of some malignant diseases $[1,2,17,18,26]$. Specifically, serum sMICA is elevated in patients with various carcinomas including gastrointestinal, lung, hematological, gynecological and urological cancers, with the extent of change reported to correlate with disease severity and/or metastasis status [24-43]. Other studies demonstrate serum SMICB elevation being of

Table 1 Demographic characteristics of the patients and healthy controls

\begin{tabular}{llll}
\hline Subject groups & $\begin{array}{l}\text { Number of } \\
\text { cases }\end{array}$ & $\begin{array}{l}\text { Sex (male/ } \\
\text { female) }\end{array}$ & $\begin{array}{l}\text { Age (years) mean } \pm \\
\text { S.D.(range) }\end{array}$ \\
\hline Carcinoma & 495 & $306 / 189$ & $53.4 \pm 13.0(12-89)$ \\
Bacterial infection & 146 & $103 / 43$ & $52.6 \pm 22.0(0.1-91)$ \\
$\begin{array}{l}\text { Candida albicans } \\
\text { infection }\end{array}$ & 14 & $3 / 11$ & $66.2 \pm 22.0(0.2-90)$ \\
$\begin{array}{l}\text { Virus infection } \\
\text { Microspironema }\end{array}$ & 344 & $217 / 127$ & $41.6 \pm 21.9(0.2-88)$ \\
pallidum & 42 & $24 / 18$ & $37.2 \pm 16.1(1-69)$ \\
Healthy controls & 141 & $81 / 60$ & $44.0 \pm 11.4(22-70)$ \\
\hline
\end{tabular}

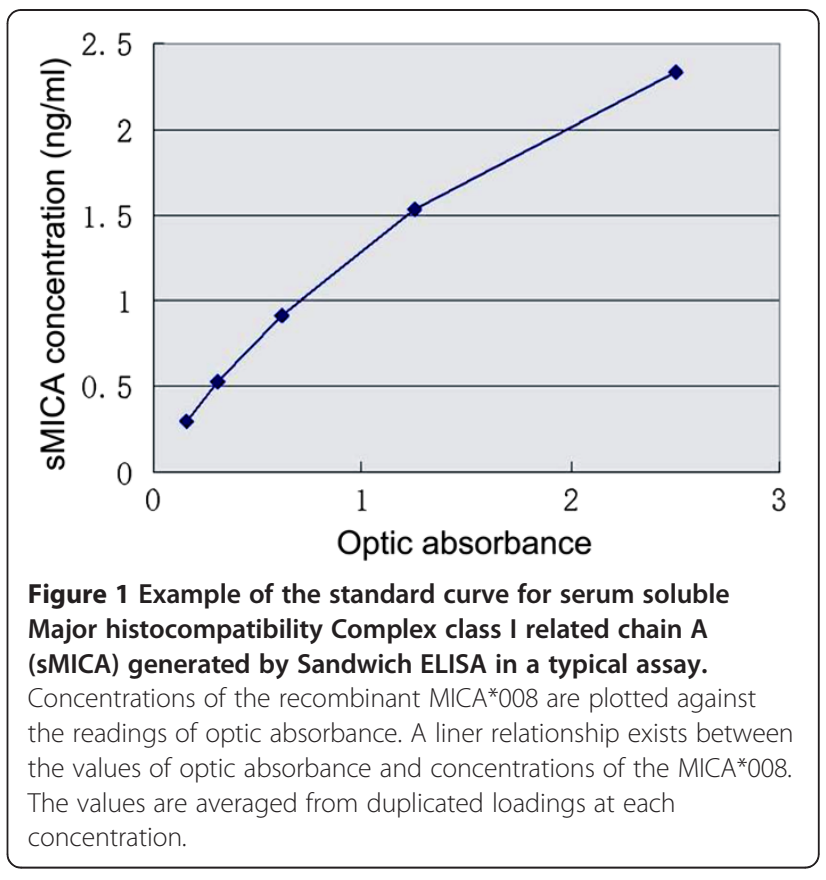

diagnostic value in cancer patients [34-43]. It should be noted that moderate increase of serum MICA/B has been demonstrated in some benign conditions, including nonmalignant tumors and chronic inflammation [36,44-50]. However, association studies on SMICA/B alteration in various infectious disorders are scarce.

In the present study, we measured serum sMICA levels by enzyme-linked immunosorbent assay (ELISA) in a large patient population from Hunan Province of China. Subjects included patients with several types of clinically diagnosed cancers, bacterial and viral infections, and healthy controls. The extent of sMICA elevation and diagnostic value, i.e., sensitivity and specificity by receiver operating characteristic (ROC) analysis, were evaluated for each disease entity. Our results point to a modulation of sMICA in malignant as well as nonmalignant disorders, which might be of clinical implications for disease diagnosis and differential diagnosis.

\section{Methods}

\section{Patients and healthy donors}

The present human subject study was approved by the ethics committee of Nan-Hua (Southern China) University; with pre-informed consent obtained from all participants. Patients $(n=1041)$ were enrolled into the first affiliated hospital of the University from October, 2007 to December, 2009. Healthy controls $(n=141)$ were outpatients who received routine physical examination during the same period. All participants were Han Chinese. The general demographic information is summarized in Table 1. The malignant tumor group included 495 cases 


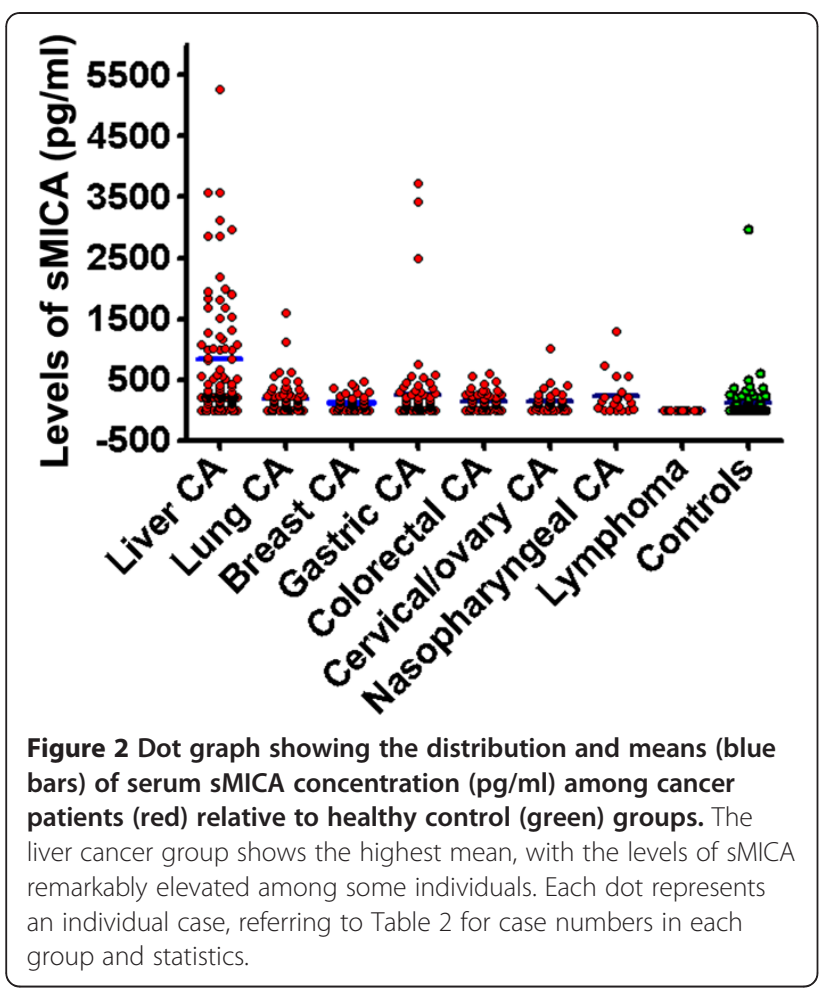

suffered from liver $(n=141)$, lung $(n=70)$, gastric $(n=77)$, intestine $(n=58)$, breast $(n=57)$, cervical and ovary $(\mathrm{n}=46)$ and nasopharyngeal $(\mathrm{n}=21)$ carcinoma, as well as lymphoma $(n=25)$. The bacterial infection group $(n=146)$ included patients with symptomatic infections by enterobacteriaceae $(n=40)$, non-fermenting Gram-negative bacteria $(\mathrm{n}=39)$, Mycobacterium tuberculosis $(n=55)$ and Gram-positive cocci $(n=12)$. The viral infection group included 344 cases with clinical symptoms caused by hepatitis virus B $(n=74)$, hepatitis virus $C(n=94)$, and other viruses $(n=176)$ including herpes simplex virus, Coxsackie virus, Epstein-Barr virus and cytomegalovirus Fourteen and 42 cases were enrolled into the Candida albicans and Microspironema pallidum infection groups, respectively. Diagnoses were established based on clinical history, imaging examination and pathological evaluation for tumor patients [including by the TNM (tumor, node, and metastasis) staging system]. For all infectious disease patients, the diagnoses were also confirmed by serological tests and/or microbiological cultures using blood and/or body fluids.

\section{Measurement of serum sMICA by ELISA}

The capture antibody was a monoclonal antibody to human sMICA (mAbAMO-1, IgG1, BAMOMAB GmbH, Habsburgerstrasse, Germany). A total of $100 \mu \mathrm{l}$ buffer containing the antibody at a concentration of $5 \mathrm{ng} / \mathrm{ml}$ was loaded into each well of 96-well plates. After antibody coating overnight at $4^{\circ} \mathrm{C}$, the plates were washed 3 times with $0.01 \mathrm{M}$ phosphate-buffered saline (PBS) containing 3\% Tween-20 (PBST). To block non-specific binding, the plates were incubated with PBS containing $15 \%$ bovine serum albumin (BSA) at $37^{\circ} \mathrm{C}$ for 2 hours, and then rinsed with PBST once. Loading samples were mix of human serum and PBS containing 15\% BSA, at a 1 to 2 ratio. For each case, $100 \mu \mathrm{l}$ sample mix was loaded in each well of the plates, incubated at $37^{\circ} \mathrm{C}$ for 2 hours. The plates were then incubated with the reporter antibody anti-MICA 6B3 (monoclonal IgG2 $\alpha$, see $[17,18])$ at $1 \mu \mathrm{g} / \mathrm{ml}(100 \mu \mathrm{l})$ at $37^{\circ} \mathrm{C}$ for 2 hours, and with horseradish peroxidase (HRP) conjugated goat anti-rat IgG antibody (100 $\mu \mathrm{l} /$ well, 1:2000) at $37^{\circ} \mathrm{C}$ for 2 hours. Binding signal was visualized using tetramethyl benzidine (TMB) as a chromogen, with optic absorbance values measured at $450 \mathrm{~nm}$ (RT-6000, Rayto Life and Analytical Sciences Co. Ltd., USA). Recombinant human sMICA (MICA*008, see $[17,18]$ ) was prepared at titered concentrations $(0.156 \mathrm{ng} / \mathrm{ml}, 0.31 \mathrm{ng} / \mathrm{ml}, 0.62 \mathrm{ng} /$ $\mathrm{ml}, 1.25 \mathrm{ng} / \mathrm{ml}, 2.5 \mathrm{ng} / \mathrm{ml}, 5.0 \mathrm{ng} / \mathrm{ml}$ ), and assayed in parallel with serum samples. All samples were assayed in triplicate.

\section{Data and statistical analysis}

Concentrations of sMICA were calculated according to the standard curve derived from MICA*008 references. Data were expressed as mean $\pm \mathrm{SD}$, and subjected to

Table 2 Levels of soluble MICA in different cancer patients

\begin{tabular}{llllll}
\hline & Number of cases & Sex (male/female) & Age (years) mean \pm SD (range) & sMICA (pg/ml) & P (vs controls) \\
\hline Liver cancer & 141 & $118 / 23$ & $52.7 \pm 11.2(24-75)$ & $743.4 \pm 110.8$ & $<0.0001$ \\
Lung cancer & 70 & $54 / 16$ & $59.5 \pm 10.5(39-79)$ & $192.3 \pm 258.2$ & 0.095 \\
Breast cancer & 57 & $0 / 57$ & $50.0 \pm 11.5(29-72)$ & $162.5 \pm 116.1$ & $>0.05$ \\
Gastric cancer & 77 & $63 / 14$ & $52.4 \pm 12.4(20-78)$ & $264.4 \pm 524.8$ & 0.075 \\
Colorectal cancer & 58 & $39 / 19$ & $58.8 \pm 16.3(13-89)$ & $176.4 \pm 147.9$ & $>0.05$ \\
Cervical/ovary cancer & 46 & $0 / 46$ & $46.3 \pm 8.9(23-70)$ & $168.3 \pm 173.3$ & $>0.05$ \\
Nasopharyngeal cancer & 21 & $19 / 2$ & $47.1 \pm 10.9(30-74)$ & $238.2 \pm 318.6$ & 0.087 \\
Lymphoma & 25 & $13 / 12$ & $48.2 \pm 13.6(17-70)$ & $140.9 \pm 137.6$ & $>0.05$ \\
Controls & 141 & $81 / 60$ & $44.0 \pm 11.4(22-70)$ & $168.5 \pm 56.7$ &
\end{tabular}



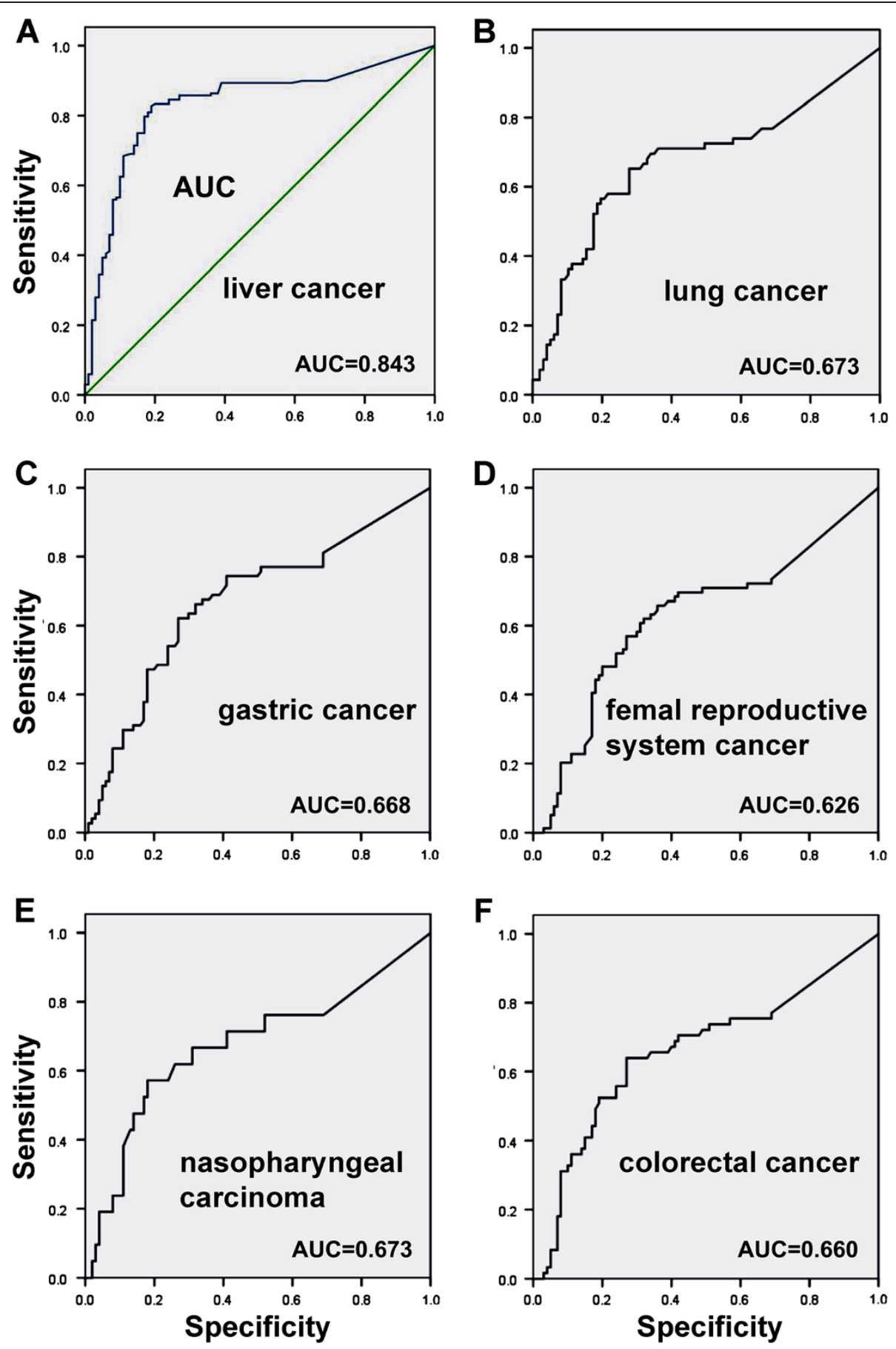

Figure 3 Receiver operating characteristic (ROC) curves illustrating the diagnostic impact of serum sMICA levels in different malignant tumors, as determined by the values of area under the ROC curve (AUC). The data indicate that test has the highest diagnostic value $(A \cup C=0.834)$ among patients of hepatic cancer relative to other malignant tumors.

One-way ANOVA test using the Prism 4.02 software (GraphPad Software, Inc., San Diego, CA, USA). The significant level was set at $\mathrm{P}<0.05$. To assess the diagnostic value of the assay, the sensitivity/specificity receiver operating characteristic (ROC) curve was generated with Excel. Cut-off level was set at the 95th percentile to a given testing group. Area under the ROC curve (AUC) (ranging from 0.5-1) was established to estimate the diagnostic value. According to clinical statistics, AUC values from 0.5 to $0.7,0.7$ to 0.9 , and $>0.9$ are suggestive of low, intermediate and high diagnostic significance, respectively. 
Table 3 Serum sMICA levels relative to hepatic cancer staging

\begin{tabular}{lllll}
\hline & $\begin{array}{l}\text { Tumor } \\
\text { grading }\end{array}$ & $\begin{array}{l}\text { Case } \\
\text { subgroups }\end{array}$ & $\begin{array}{l}\text { sMICA } \\
\text { (pg/ml) }\end{array}$ & $\begin{array}{l}\text { P (relative } \\
\text { to T1) }\end{array}$ \\
\hline TNM staging & T1 & $4.3 \%(6)$ & $389.6 \pm 153.3$ & \\
& T2 & $23.4 \%(33)$ & $712.3 \pm 108.6$ & $<0.0001$ \\
& T3 & $59.5 \%(84)$ & $883.7 \pm 133.2$ & $<0.0001$ \\
& T4 & $12.8 \%(18)$ & $699.1 \pm 212.5$ & $<0.0001$ \\
Pathological & high & $56.1 \%(79)$ & $718.9 \pm 113.6>0.05$ \\
Differentiation & Intermediate & $33.3 \%(47)$ & $753.5 \pm 132.1$ & $>0.05$ \\
& low & $10.6 \%(15)$ & $840.8 \pm 232.2$ & $>0.05$ \\
\hline
\end{tabular}

\section{Results}

Serum levels and diagnostic impact of sMICA in malignant diseases

A linear relationship between sMICA concentrations and optic absorbance readings was established by the calibration assays using the recombinant human sMICA (Figure 1). Accordingly, serum levels of sMICA were obtained from the patient and control groups. Overall, patients with liver cancer had the highest levels of sMICA (743.4 \pm 110.8 $\mathrm{pg} / \mathrm{ml})$ relative to other types of cancers and healthy controls $(168.5 \pm 56.7, \mathrm{pg} / \mathrm{ml}$ ) (Table 1). Patients with gastric cancer ranked the second highest elevation of sMICA levels among the cancer groups $(264.4 \pm 524.8 \mathrm{pg} / \mathrm{ml})$. In contrast, serum levels of sMICA in patients with female reproductive system tumors and malignant lymphoma (140.9 \pm 137.6 $\mathrm{pg} / \mathrm{ml}$ and $162.5 \pm 116.1 \mathrm{pg} / \mathrm{ml}$ ) appeared to be comparable to that in control (Figure 2, Table 2). One-way ANOVA analysis showed a significant difference among the cancer and control groups $(\mathrm{P}<0.0001, \mathrm{~F}=80.53, \mathrm{df}=8,627)$. Posthoc tests indicated that the levels of sMICA in the liver cancer group were significantly different relative to the control $(\mathrm{P}<0.0001)$ as well as the remaining cancer groups $(\mathrm{P}<0.0001)$. The differences between the gastric cancer $(\mathrm{P}=0.075)$ relative to control groups and between nasopharyngeal cancer $(\mathrm{P}=0.087)$ relative to control groups, were approaching statistical significance (Table 2).

The diagnostic impact of sMICA in the above cancer groups was analyzed by ROC curve fitting (Figure 3). The AUC value was 0.843 for hepatic cancer patients, which was of high diagnostic value (Figure $2 \mathrm{~A}$ ). The AUC values were $0.673,0.668,0.626,0.673$ and 0.660 for lung, gastric, female reproductive, nasopharyngeal and colorectal cancers, respectively. Thus, the AUC values of the non-hepatic malignant groups appeared to be of a relatively low diagnostic impact (Figure 3B-F).

Given the potential high diagnostic implication of sMICA among the liver cancer patients, we further analyzed whether serum sMICA levels were correlated to TNM staging and the pathological grade of the tumor. Levels of sMICA were $389.6 \pm 153.3,712.3 \pm 108.6,883.7 \pm 133.2$ and $699.1 \pm 212.5 \mathrm{pg} / \mathrm{ml}$ in the subgroups with hepatic cancers classified as T1, T2, T3 and T4 stages, respectively (Table 3). Among all liver cancer patients, about 4.3\%, 23.4\%, 59.5\% and $12.8 \%$ of the cases had the cancers graded as T1, T2, T3 and T4 clinical stages, respectively. The levels of sMICA were significantly higher for T1-T4 groups relative to controls $(\mathrm{P}<0.0001, \mathrm{~F}=655.8, \mathrm{df}=4,277)$. Posthoc tests indicated statistical differences for the $\mathrm{T} 1$ relative to $\mathrm{T} 2$, $\mathrm{T} 3$ and T4 subgroups ( $\mathrm{P}<0.001$ for all subgroups), the $\mathrm{T} 2$ relative to T3 subgroups $(\mathrm{P}<0.001)$ and the T3 relative to T4 subgroups $(\mathrm{P}<0.001)$. However, while the data were analyzed against the pathologically defined differentiation grading, no statistical differences were found between the high, intermediate and low differentiation subgroups (Table 3).

\section{Serum levels and diagnostic impact of sMICA in infectious diseases}

We analyzed serum sMICA levels among patients suffered from several bacterial (enterobacteriaceae, non-fermenting Gram-negative bacteria, Gram-positive cocci, M. tuberculosis, Microspironema pallidum), viral (hepatitis B, hepatitis $\mathrm{C}$ and other viruses) and fungi (Canidia albicans) infections

Table 4 Levels of soluble MICA in infectious diseases patients

\begin{tabular}{|c|c|c|c|c|c|}
\hline Pathogens & Number of cases & Sex (male/female) & Age (year) mean \pm S.D. (range) & sMICA (pg/ml) & $\mathrm{P}$ (vs controls) \\
\hline Enterobacteriaceae & 40 & $26 / 14$ & $59.2 \pm 22.1(1-91)$ & $492.2 \pm 295.9$ & $<0.001$ \\
\hline M. tuberculosis & 55 & $41 / 14$ & $56.1 \pm 19.0(2-88)$ & $493.9 \pm 256.4$ & $<0.001$ \\
\hline Non-fermenting Gram-negative bacteria & 39 & $26 / 13$ & $49.4 \pm 22.1(5-90)$ & $384.1 \pm 416.2$ & $<0.001$ \\
\hline Gram-positive cocci & 12 & $10 / 2$ & $38.9 \pm 21.9(2-84)$ & $542.3 \pm 382.9$ & $<0.001$ \\
\hline Hepatitis B virus & 74 & $45 / 29$ & $44.1 \pm 16.6(15-87)$ & $472.4 \pm 103.6$ & $<0.001$ \\
\hline Hepatitis C Virus & 94 & $48 / 46$ & $50.3 \pm 15.4(18-86)$ & $474.9 \pm 123.1$ & $<0.001$ \\
\hline Other viruses* & 176 & $124 / 52$ & $12.9 \pm 19.1(1-75)$ & $251.2 \pm 256.3$ & $>0.05$ \\
\hline Microspironema pallidum & 42 & $24 / 18$ & $37.2 \pm 16.1(1-69)$ & $365.8 \pm 476.6$ & $<0.001$ \\
\hline Canidia albicans & 14 & $11 / 3$ & $66.2 \pm 22.0(0.2-90)$ & $285.0 \pm 215.3$ & $>0.05$ \\
\hline Healthy controls & 141 & $81 / 60$ & $44.0 \pm 11.4(22-70)$ & $168.5 \pm 56.7$ & \\
\hline
\end{tabular}

*: including herpes simplex virus, Coxsackie virus, Epstein-Barr virus, cytomegalovirus, hepatitis $\mathrm{A}$ virus and hepatitis $\mathrm{E}$ virus. 


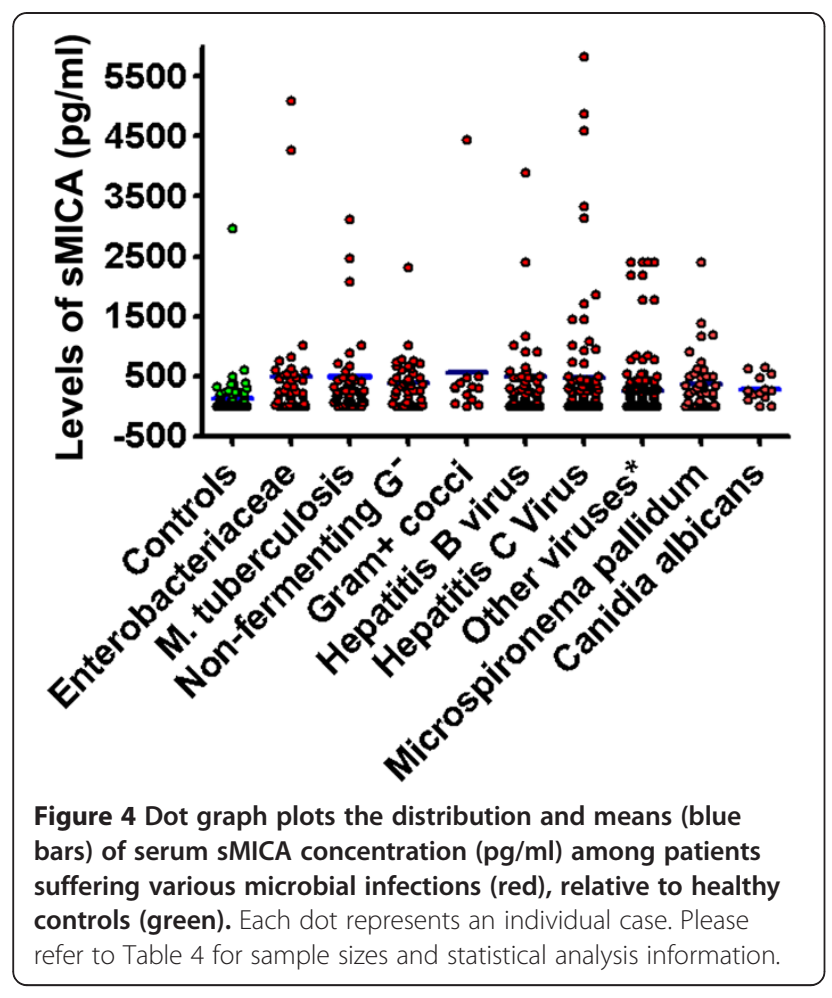

relative to the healthy controls, as detailed in Table 4. All infections were clinically established, with the diagnoses also confirmed by microbiological and serological laboratory tests. A significant difference existed among the infectious disease and control groups by one-way ANOVA $(P=0.0001, F=21.88, d f=9,677)$. Specifically, levels of sMICA were elevated among all infectious diseases, except for the Canidia albicans and "other viruses" groups, relative to controls as indicated by posthoc paired comparison (Figure 4; Table 4). Of note, the hepatitis $B$ and $C$ virus infection groups showed significant sMICA elevation relative to the "other viruses" group $(\mathrm{P}<0.001)$. In sum, a certain extent of elevation of serum sMICA levels appeared to be associated with most bacterial infections as well as hepatitis $\mathrm{B}$ and C. In contrast, levels of sMICA in patients with Canidia albicans fungi infection appeared to be comparable to that in normal controls.

As with the cancer disease groups, the diagnostic values of sMICA in the infection disease groups were assessed by ROC curve fitting. The AUC value for hepatitis B was 0.712 , for hepatitis $C$ was 0.701 , syphilis helicoid, 0.707 , tubercle bacilli, 0.766, gram-negative bacilli, 0.742 , and for other virus infections, 0.672 (Figure 5A-F).

\section{Discussion}

Previous association studies have shown a link of polymorphism of MICA/B and/or alteration in SMICA/B to cancers, autoimmunity and host-graft reaction
[11,17,19,25,26,34-36]. Serum sMICA/B levels are potential biomarkers of pathogenic implications for these disease conditions. For instance, upregulation of sMICA/B may be involved in the escape of tumor cells from immune cell attack and clearance [1-3,19,26,27]. Accordingly, inhibition of sMICA/B production and/or preventing their shedding from cell surface may be of therapeutic potential in treating these human diseases [24,37]. A better understanding of sMICA/B alteration in a broad disease spectrum is of important clinical relevance. Using a relatively large sample pool, we show here elevations of serum sMICA in association with infectious diseases in addition to cancers in a southern Chinese Han population.

Elevations of serum sMICA and SMICB have been shown in a number of malignant diseases, with sMICA potentially being more suitable than SMICB for early diagnosis of some cancers $[33,34]$. Specifically, lung, breast, digestive system (hepatic, pancreas, gastric, colorectal) and urological cancers (prostate and renal) are associated with significant increase of serum SMICA relative to healthy controls as well as benign tumors. Consistent with these reports, the present study finds elevation of serum sMICA among Chinese patients with several types of malignant tumors, which are, or are approaching to, statistical significance relative to controls. In particular, the elevation appears to be especially dramatic in the hepatic cancer patients. The present data also suggest a certain extent of correlation of sMICA levels to the clinical stages of hepatic cancer. Thus, a significant difference exists between T2, T3 and T4 as compared to $\mathrm{T} 1$ stage cases, as well as between $\mathrm{T} 2$ and $\mathrm{T} 3$ stage patients. Somewhat surprising, the levels of sMICA are reduced in T4 compared with T3 stage patients in our studied cohort. One possible explanation for this finding may be that the lowering of sMICA in the T4 stage group occurs as a result of severe systematic or hepatic deficiency in cell function, such as failure of protein synthesis, among end-stage cancer patients. The ROC analysis in the present study reveals moderate diagnostic value for liver cancer, but marginal impacts for other cancer types. Taken together, serum sMICA and ROC analyses in the present study suggest a trend of elevation of the protein in liver, lung and laryngeal carcinomas in Chinese population, with the laboratory test being of significant value in the diagnosis and prognosis of hepatic cancer.

Evidence suggests that infections by microbiological pathogens may alter the expression and functionality of membrane bound MICA/B [2,4,16,36]. For instances, changes in MICA/B and/or NKG2D levels and their activities are associated with infections caused by human cytomegalovirus [28], hepatitis B and C viruses [14,29], herpes simplex virus [30], human immunodeficiency virus [31] and vesicular stomatitis virus [46]. Sex-transmitted Chlamydia trachomatis may also down-regulate MICA/B expression on cell membrane $[16,44,50]$. However, whether 

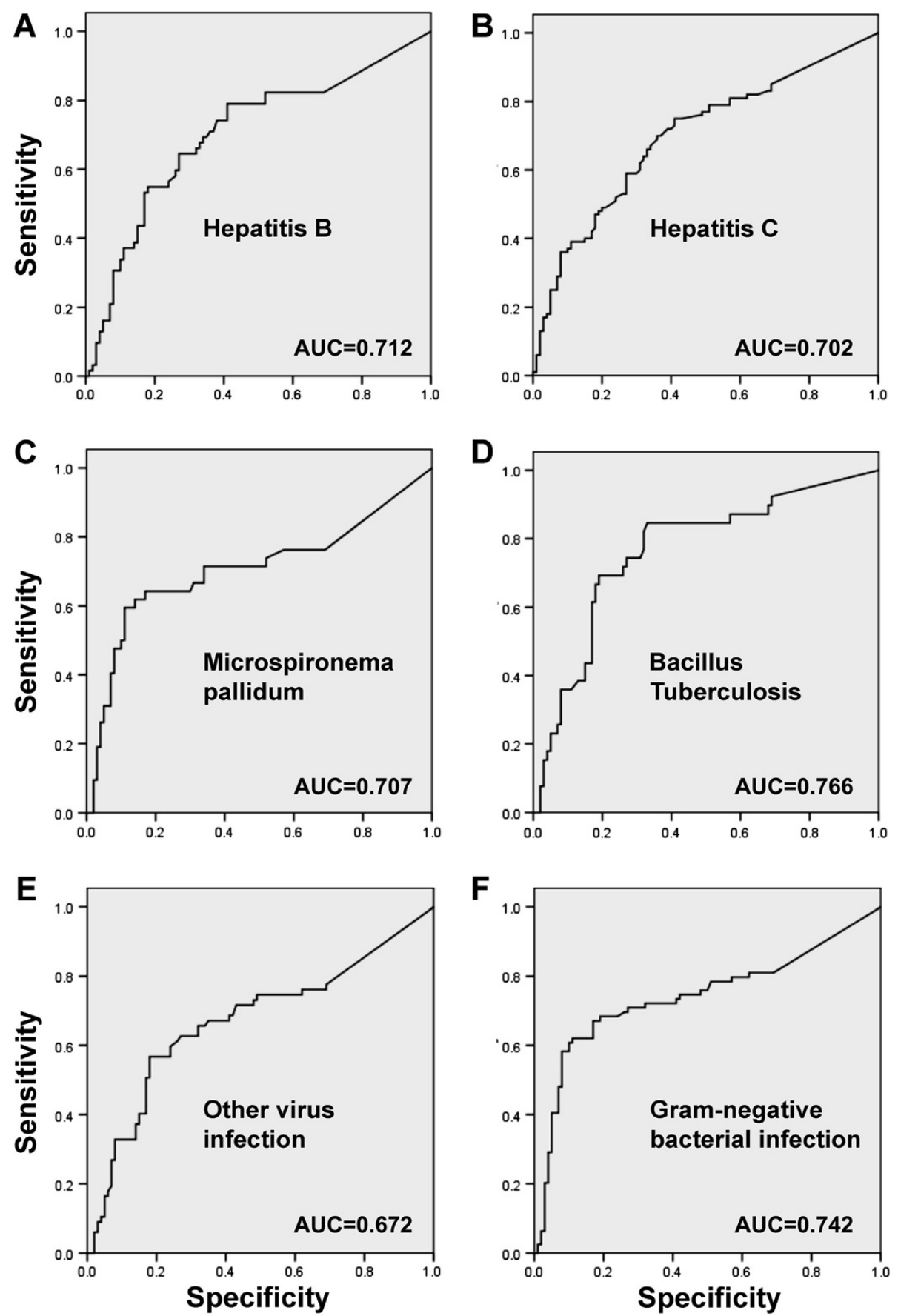

Figure 5 Receiver operating characteristic (ROC) curves illustrating the diagnostic impact of serum sMICA levels in different infectious diseases, with the values of area under the ROC curve (AUC) labeled for each type of infections. The data indicate that test has an intermediate diagnostic impact (AUC > 0.7) among patients with infections by hepatitis B (A) and C (B) viruses; Microspironema pallidum (C), bacillus tuberculosis (D) and Gram-negative bacterium (F). In contrast, the diagnostic value is low in the patient group with infections including herpes simplex virus, Coxsackie virus, Epstein-Barr virus, cytomegalovirus, hepatitis A virus and hepatitis E virus (E).

infections caused by microbiological pathogens also affect serum sMICA levels remains poorly understood.

The present study provides evidence that serum sMICA levels are elevated in various infectious diseases by microbiological pathogens. In detail, sMICA levels are increased to above 2 fold in bacterial infections with enterobacteriaceae, mycobacterium tuberculosis, Gram-positive cocci, non-fermenting Gram-negative bacteria and Microspironema pallidum. Among virus infectious diseases, sMICA levels are significantly increased in hepatitis B and C. 
However, we fail to find significant elevations of sMICA among patients infected by herpes simplex virus, Coxsackie virus, Epstein-Barr virus, cytomegalovirus, hepatitis A virus and hepatitis $\mathrm{E}$ virus, and by the Canidia albicans fungus. These data implicate that increased shedding of membrane MICA molecules presumably from infected/inflammatory cells may occur in several types of infectious diseases, which may lead to the observed rise of sMICA in serum. Given the findings of the elevation in many but not all infectious diseases, one may hypothesize that the extent of sMICA elevation could be potentially relevant to either the pathogens, or alternatively, the amount of involvement of infected cells in the body. Our ROC analyses suggest that serum sMICA measurement appears to have an intermediate diagnostic value for infections with hepatitis B and $\mathrm{C}$ virus, Microspironema pallidum, tuberculosis and Gram-negative bacteria (i.e., AUC > 0.7).

\section{Conclusions}

The present study shows elevation of serum sMICA levels in patients suffering from several types of malignant and infectious diseases relative to healthy controls in a southern China population. The data suggest that serum sMICA is of potential diagnostic value for some bacterial and viral infections, in addition to malignant disorders as reported previously. Based on our currently findings, microbiological infections should be considered as a part of differential diagnosis while evaluating serum sMICA changes in other disease conditions.

\section{Competing interests}

The authors declare that they have no competing interests.

\section{Authors' contributions}

$X J, P Y$ and $R C$ designed the experiment. $X J, Z H, Q Z, Y J, X W, Y L$ and $G J$ collected the samples and performed experiments. XJ, JH, LZ and XXY analyzed data. XJ and XXY wrote the paper. All authors read and approved the final manuscript.

\section{Acknowledgements}

The authors appreciate the patients for their blood donation, the stuff of the in- and out-patient laboratory units of the First Affiliated Hospital of Nanhua University for sample collection. We thank Dr. Zou Yizhou for kindly providing the anti-MICA 6B3 antibody and the recombinant human MICA*008 protein, and Ye Cao for secretary assistance. This work was supported in part by the National Natural Science Foundation of China (general programs \#81172542 and \#30870135) and a postdoctoral fund from Central South University.

\section{Author details}

${ }^{1}$ The First Affiliated Hospital, Nanhua University, Hengyang 421001, China. ${ }^{2}$ Department of Immunology, Xiangya School of Medicine, Central South University, Changsha, Hunan 410078, China. ${ }^{3}$ Department of Anatomy and Neurobiology, Xiangya School of Medicine, Central South University, Changsha, Hunan 410013, China.

Received: 9 August 2012 Accepted: 23 November 2012 Published: 26 November 2012

\section{References}

1. Groh V, Wu J, Yee C, Spies T: Tumour-derived soluble MIC ligands impair expression of NKG2D and T-cell activation. Nature 2002, 419:734-738.

2. Groh V, Rhinehart R, Randolph-Habecker J, Topp MS, Riddell SR, Spies T: Costimulation of CD8alphabeta T cells by NKG2D via engagement by MIC induced on virus-infected cells. Nat Immunol 2001, 2:255-260.

3. Bauer S, Groh V, Wu J, Steinle A, Phillips JH, Lanier LL, Spies T: Activation of NK Cells and T Cells by NKG2D, a Receptor for Stress-Inducible MICA. Science 1999, 285:727-729.

4. Tieng $V$, Le Bouguénec $C$, du Merle L, Bertheau $P$, Desreumaux $P$, Janin $A$, Charron D, Toubert A: Binding of Escherichia coli adhesin AfaE to CD55 triggers cell-surface expression of the MHC class I-related molecule MICA. Proc Natl Acad Sci USA 2002, 99:2977-2982.

5. Shiina T, Tamiya G, Oka A, Takishima N, Inoko H: Genome sequencing analysis of the $1.8 \mathrm{Mb}$ entire human MHC class I region. Immunol Rev 1999, 167:193-199.

6. Bahram S, Shiina T, Oka A, Tamiya G, Inoko H: Genomic structure of the human MHC class I MICB gene. Immunogenetics 1996, 45:161-162.

7. Kulski JK, Dunn DS, Hui J, Martinez P, Romphruk AV, Leelayuwat C, Tay GK, Oka A, Inoko H: Alu polymorphism within the MICB gene and association with HLA-B alleles. Immunogenetics 2002, 53:975-979.

8. Ando H, Mizuki N, Ota M, Yamazaki M, Ohno S, Goto K, Miyata Y, Wakisaka $\mathrm{K}$, Bahram S, Inoko H: Allelic variants of the human MHC class I chain-related B gene (MICB). Immunogenetics 1997, 46:499-508.

9. Visser CJ, Tilanus MG, Schaeffer V, Tatari Z, Tamouza R, Janin A, Charron D: Sequencing-based typing reveals six novel MHC class I chain-related gene B (MICB) alleles. Tissue Antigens 1998, 51:649-652.

10. Fischer G, Argüello JR, Pérez-Rodríguez M, McWhinnie A, Marsh SG, Travers PJ, Madrigal JA: Sequence-specific oligonucleotide probing for MICB alleles reveals associations with MICA and HLA-B. Immunogenetics 2000, 51:591-599.

11. Glas J, Martin K, Brünnler G, Kopp R, Folwaczny C: MICA, MICB and C1_4_1 polymorphism in Crohn's disease and ulcerative colitis. Tissue Antigens 2001, 58:243-249.

12. Liu X, Tian W, Li L, Cai J: Characterization of the major histocompatibility complex class I chain-related gene B (MICB) polymorphism in a northern Chinese Han population: the identification of a new MICB allele, MICB*023. Hum Immunol 2011, 72:727-732.

13. Mizuki N, Ota M, Kimura M, Ohno S, Ando H, Katsuyama Y, Yamazaki M, Watanabe K, Goto K, Nakamura S, Bahram S, Inoko H: Triplet repeat polymorphism in the transmembrane region of the MICA gene: a strong association of six GCT repetitions with Behçet disease. Proc Natl Acad Sci USA 1997, 94:1298-1303.

14. Karacki PS, Gao X, Thio CL, Thomas DL, Goedert JJ, Vlahov D, Kaslow RA, Strathdee S, Hilgartner MW, O'Brien SJ, Carrington M: MICA and recovery from hepatitis C virus and hepatitis B virus infections. Genes Immun 2004, 5:261-266.

15. Liu CJ, Lui MT, Chen HL, Lin SC, Chang KW: MICA and MICB overexpression in oral squamous cell carcinoma. J Oral Pathol Med 2007, 36:43-47.

16. Mei B, Luo Q, Du K, Huo Z, Wang F, Yu P: Association of MICA gene polymorphisms with Chlamydia trachomatis infection and related tubal pathology in infertile women. Hum Reprod 2009, 24:3090-3095.

17. Zou Y, Stastny P, Süsal C, Döhler B, Opelz G: Antibodies against MICA antigens and kidney-transplant rejection. N Engl I Med 2007, 357:1293-1300.

18. Zou Y, Yang $X$, Jiang $X$, Wang H, Hao Q, Liu Y, Yu P: High levels of soluble major histocompatibility complex class I related chain A (MICA) are associated with biliary cast syndrome after liver transplantation. Transpl Immunol 2009, 21:210-214.

19. Choy MK, Phipps ME: MICA polymorphism: biology and importance in immunity and disease. Trends Mol Med 2010, 16:97-106.

20. Jiang X, Zou Y, Huo Z, Yu P: Association of major histocompatibility complex class I chain-related gene A microsatellite polymorphism and hepatocellular carcinoma in South China Han population. Tissue Antigens 2011, 78:143-147.

21. Luo QZ, Lin L, Gong Z, Mei B, Xu YJ, Huo Z, Yu P: Positive association of major histocompatibility complex class I chain-related gene $A$ polymorphism with leukemia susceptibility in the people of Han nationality of Southern China. Tissue Antigens 2011, 78:178-184. 
22. Gong Z, Luo QZ, Lin L, Su YP, Peng HB, Du K, Yu P, Wang SP: Association of MICA gene polymorphisms with liver fibrosis in schistosomiasis patients in the Dongting Lake region. Braz J Med Biol Res 2012, 45:222-229.

23. Gaudieri S, Leelayuwat C, Tay GK, Townend DC, Dawkins RL: The major histocompatability complex (MHC) contains conserved polymorphic genomic sequences that are shuffled by recombination to form ethnic-specific haplotypes. J Mol Evol 1997, 45:17-23.

24. Salih HR, Rammensee HG, Steinle A: Cutting edge: down-regulation of MICA on human tumors by proteolytic shedding. J Immunol 2002 169:4098-4102.

25. Salih HR, Antropius H, Gieseke F, Lutz SZ, Kanz L, Rammensee HG, Steinle A: Functional expression and release of ligands for the activating immunoreceptor NKG2D in leukemia. Blood 2003, 102:1389-1396.

26. Salih HR, Holdenrieder S, Steinle A: Soluble NKG2D ligands: prevalence, release, and functional impact. Front Biosci 2008, 13:3448-3456.

27. Raffaghello L, Prigione I, Airoldi I, Camoriano M, Levreri I, Gambini C, Pende D, Steinle A, Ferrone S, Pistoia V: Downregulation and/or release of NKG2D ligands as immune evasion strategy of human neuroblastoma. Neoplasia 2004, 6:558-568.

28. Chalupny NJ, Rein-Weston A, Dosch S, Cosman D: Down-regulation of the NKG2D ligand MICA by the human cytomegalovirus glycoprotein UL142. Biochem Biophys Res Commun 2006, 21:175-181.

29. Chen $Y$, Cheng $M$, Tian Z: Hepatitis $B$ virus down-regulates expressions of MHC class I molecules on hepatoplastoma cell line. Cell Mol Immunol 2006, 3:373-378

30. Schepis D, Damato M, Studahl M, Bergström T, Kärre K, Berg L: Herpes simplex virus infection downmodulates NKG2D ligand expression. Scand J Immunol 2009, 69:429-436.

31. Nolting A, Dugast AS, Rihn S, Luteijn R, Carrington MF, Kane K, Jost S, Toth I, Nagami E, Faetkenheuer G, Hartmann P, Altfeld M, Alter G: MHC class I chain-related protein A shedding in chronic HIV-1 infection is associated with profound NK cell dysfunction. Virology 2010, 406:12-20.

32. Arreygue-Garcia NA, Daneri-Navarro A, del Toro-Arreola A, Cid-Arregui A, Gonzalez-Ramella O, Jave-Suarez LF, Aguilar-Lemarroy A, Troyo-Sanroman R, Bravo-Cuellar A, Delgado-Rizo V, Garcia-Iglesias T, Hernandez-Flores G, Del Toro-Arreola S: Augmented serum level of major histocompatibility complex class I-related chain A (MICA) protein and reduced NKG2D expression on NK and T cells in patients with cervical cancer and precursor lesions. BMC Cancer 2008, 8:16.

33. Kohga K, Takehara T, Tatsumi T, Ohkawa K, Miyagi T, Hiramatsu N, Kanto T, Kasugai T, Katayama K, Kato M, Hayashi N: Serum levels of soluble major histocompatibility complex (MHC) class I-related chain A in patients with chronic liver diseases and changes during transcatheter arterial embolization for hepatocellular carcinoma. Cancer Sci 2008, 99:1643-1649.

34. Holdenrieder S, Stieber P, Peterfi A, Nagel D, Steinle A, Salih HR: Soluble MICA in malignant diseases. Int J Cancer 2006, 118:684-687.

35. Holdenrieder S, Stieber P, Peterfi A, Nagel D, Steinle A, Salih HR: Soluble MICB in malignant diseases: analysis of diagnostic significance and correlation with soluble MICA. Cancer Immunol Immunother 2006 55:1584-1589

36. Holdenrieder S, Eichhorn P, Beuers U, Samtleben W, Stieber P, Nagel D, Peterfi A, Steinle A, Salih HR: Soluble NKG2D ligands in hepatic autoimmune diseases and in benign diseases involved in marker metabolism. Anticancer Res 2007, 27:2041-2045.

37. Suárez-Alvarez B, López-Vázquez A, Baltar JM, Ortega F, López-Larrea C Potential role of NKG2D and its ligands in organ transplantation: new target for immunointervention. Am J Transplant 2009, 9:251-257.

38. Zhao J, Jiang Y, Lei Y, Zou K, Wang C, Huang S, Yi F, Xia B: Functional MICA-129 polymorphism and serum levels of soluble MICA are correlated with ulcerative colitis in Chinese patients. J Gastroenterol Hepatol 2011, 26:593-598.

39. Boukouaci W, Busson M, Peffault de Latour R, Rocha V, Suberbielle C, Bengoufa D, Dulphy N, Haas P, Scieux C, Amroun H, Gluckman E, Krishnamoorthy R, Toubert A, Charron D, Socié G, Tamouza R: MICA-129 genotype, soluble MICA, and anti-MICA antibodies as biomarkers of chronic graft-versus-host disease. Blood 2009, 114:5216-5224.

40. Rebmann V, Schütt P, Brandhorst D, Opalka B, Moritz T, Nowrousian MR, Grosse-Wilde H: Soluble MICA as an independent prognostic factor for the overall survival and progression-free survival of multiple myeloma patients. Clin Immunol 2007, 123:114-120.
41. von Lilienfeld-Toal M, Frank S, Leyendecker C, Feyler S, Jarmin S, Morgan R, Glasmacher A, Märten A, Schmidt-Wolf IG, Brossart P, Cook G: Reduced immune effector cell NKG2D expression and increased levels of soluble NKG2D ligands in multiple myeloma may not be causally linked. Cancer Immunol Immunother 2010, 59:829-839.

42. Pagés F, Kroemer G: Prognostic impact of anticancer immune responses: an introduction. Semin Immunopathol 2011, 33:317-319.

43. Tamaki S, Kawakami M, Ishitani A, Kawashima W, Kasuda S, Yamanaka Y, Shimomura H, Imai Y, Nakagawa Y, Hatake K, Kirita T: Soluble MICB serum levels correlate with disease stage and survival rate in patients with oral squamous cell carcinoma. Anticancer Res 2010, 30:4097-5101.

44. Hook CE, Telyatnikova N, Goodall JC, Braud VM, Carmichael AJ, Garcia-Suarez O, Martínez-Borra J, López-Vázquez A, Rodrigo L, Gonzalez S, López-Larrea C: Effects of Chlamydia trachomatis infection on the expression of natural killer (NK) cell ligands and susceptibility to NK cell lysis. Clin Exp Immunol 2004, 138:54-60

45. Fernández-Morera JL, Rodríguez-Rodero S, Lahoz C, Tuñon A, Astudillo A et al: Soluble MHC class I chain-related protein B serum levels correlate with disease activity in relapsing-remitting multiple sclerosis. Hum Immunol 2008, 69:235-240.

46. Jensen $H$, Andresen L, Nielsen J, Christensen JP, Skov S: Vesicular stomatitis virus infection promotes immune evasion by preventing NKG2D-ligand surface expression. PLoS One 2011, 6:e23023.

47. Schrambach S, Ardizzone M, Leymarie V, Sibilia J, Bahram S: In vivo expression pattern of MICA and MICB and its relevance to auto-immunity and cancer. PLoS One 2007, 2:e518.

48. Wu JD, Higgins LM, Steinle A, Cosman D, Haugk K, Plymate SR: Prevalent expression of the immunostimulatory MHC class I chain-related molecule is counteracted by shedding in prostate cancer. $J$ Clin Invest 2004, 114:560-568.

49. Jinushi M, Vanneman M, Munshi NC, Tai YT, Prabhala RH, Ritz J, Neuberg D, Anderson KC, Carrasco DR, Dranoff G: MHC class I chain-related protein A antibodies and shedding are associated with the progression of multiple myeloma. Proc Natl Acad Sci USA 2008, 105:1285-1290

50. Ibana JA, Aiyar A, Quayle AJ, Schust DJ: Modulation of MICA on the surface of Chlamydia trachomatis-infected endocervical epithelial cells promotes NK cell-mediated killing. FEMS Immunol. Med Microbio/ 2012 , 65:32-42.

doi:10.1186/1471-2172-13-62

Cite this article as: Jiang et al.: Elevation of soluble major histocompatibility complex class I related chain A protein in malignant and infectious diseases in Chinese patients. BMC Immunology 2012 13:62.

\section{Submit your next manuscript to BioMed Central and take full advantage of:}

- Convenient online submission

- Thorough peer review

- No space constraints or color figure charges

- Immediate publication on acceptance

- Inclusion in PubMed, CAS, Scopus and Google Scholar

- Research which is freely available for redistribution 